専門医症例報告

\author{
睡眠時ブラキシズム患者の審美回復に \\ ラミネートベニア法で対処した 1 症例 \\ 岩佐 文則

\section{A Case Report of Esthetic Therapy with Laminate Veneers in a Patient with Sleep Bruxism}

Fuminori Iwasa

抄 録

症例の概要 : 患者は 30 歳女性。上顎前歯部のラミネートベニアの変色と正中離開を主訴に来院し，同部 の審美障害と診断された。また，起床時の咀嚼筋症状と咬耗から睡眠時ブラキシズムが強く疑われた。審 美障害に対しては再度ラミネートベニア修復を行い，睡眠時ブラキシズムに対しては上顎オクルーザルス プリントにて対応し良好な予後が得られた。

考察：睡眠時ブラキシズム患者であっても，上顎オクルーザルスプリントを製作し夜間装着することで, ラミネートベニアを用いた歯冠修復治療の良好な予後が得られると考えられた。

結論：睡眠時ブラキシズムの的確な診断と合理的な対応を行うことが，予知性の高い補綴歯科治療を行う 上で重要である。

和文キーワード

睡眠時ブラキシズム，ラミネートベニア, スプリント

\title{
ABSTRACT
}

Patient: The patient was a 30-year-old woman, who presented with a chief complaint of cosmetic disturbance by diastema and discolored upper front teeth. The patient was diagnosed as having grinding-type sleep bruxism (SB) after clinical examinations. She was treated with porcelain laminate veneers (PLV) for the upper front teeth and also provided with a full-coverage maxillary occlusal splint for SB, which resulted in a favorable prognosis.

Discussion: PLVs are generally contraindicated for patients with SB. Application of an occlusal splint can allow a favorable prognosis even after PLV restoration.

Conclusion: Accurate diagnosis and appropriate management of SB are essential in order to secure a favorable prognosis for prosthodontic treatment, especially in the case of all-ceramic restorations such as PLVs.

\section{Key words}

sleep bruxism, porcelain laminate veneer (PLV), occlusal splint

昭和大学歯学部歯科補綴学講座

Department of Prosthodontics, School of Dentistry, Showa University

受付 : 2013 年 8 月 27 日/受理 : 2013 年 11 月 25 日

Received on August 27, 2013/Accepted on November 25, 2013 


\section{I．緒言}

睡眠時ブラキシズムは補綴歯科治療の予後不良のリ スクファクターであり，その評価・対応の成否は補綴 装置の予後を大きく左右する。

上顎前歯部のラミネートベニア修復のチッピング, 変色，正中離開を主訴とし，問診と臨床診断から睡眠 時ブラキシズムが強く疑われた患者に対して，ラミ ネートベニア法による審美修復を再度行い，オクルー ザルスプリント療法を併用することにより，良好な予 後を得ることができたので報告する.

\section{II. 症例の概要}

患者 : 30 歳, 女性.

初診日：2007 年 1 月 20 日.

主訴：上顎前歯のチッピング，着色および正中離開 による審美不良。

既往歴：特記事項なし.

現病歴：数年前にラミネートベニアによる上顎前歯 の治療を行ったが，上顎左側犬歯（|3)，上顎右側中切 歯（1」）が何度かチッピングを起こしその都度コンポ ジットレジンにて補填した。 今回上顎左側犬歯 $(\lfloor 3)$ の ベニアが脱離，また年々正中離開も進んできたため審 美性の回復と精査加療を求めて来院した.

現症 : 上顎の 6 前歯にはすでにポーセレンラミネー トベニア (Porcelain Laminate Veneer; PLV) が装着 されており, 上顎右側中切歯（1」）の切端がチッピング, 正中離開も認められた（図 1)。チッピング部はコンポ ジットレジンにて充填されていたが，変色を起こして

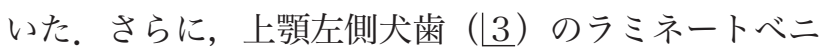
アが脱離していた。腔清掃状態は良好で歯列・咬合・ 歯周組織に異常は認められない.

検査結果：X線検査（図 2) 並びに歯周組織検査（表 1）において歯周病学的な問題は認められず，また埋 伏歯も見られなかった。患者は上顎前歯の正中離開と 着色以外に歯冠形態や歯列に対する審美的な不満はな く, 現に顔貌と口唇との調和並びに歯冠長と幅径のバ ランスも標準的な範囲内であった。

診断および治療方針：上顗 6 前歯の色調は患者の希 望と両側小臼歯との調和から A-2 とした（図 3)。咬合 関係はアングルのクラス IIIでやや切端咬合であるが, アンテリアガイダンスおよびセントリックストップな どの咬合機能は正常範囲と判断した（図 4)。また，顎 関節の状態として開口障害，開口時の雑音，下顎運動 時の疼痛などは見られなかった。補綴学会策定症型分 類 I-1（2）では Level I であった。

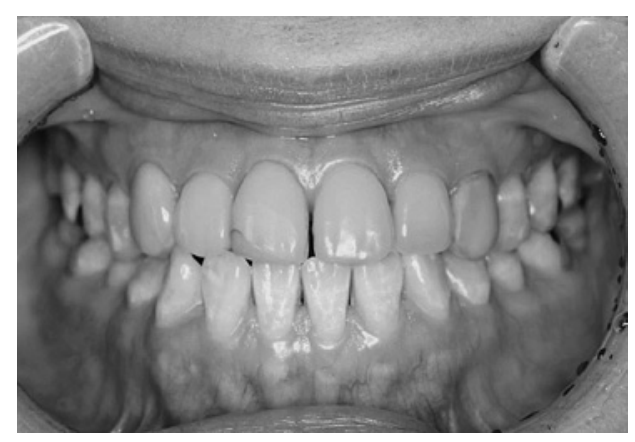

図 1 Intraoral photograph from anterior view at first examination

初診時の口腔内写真正面観

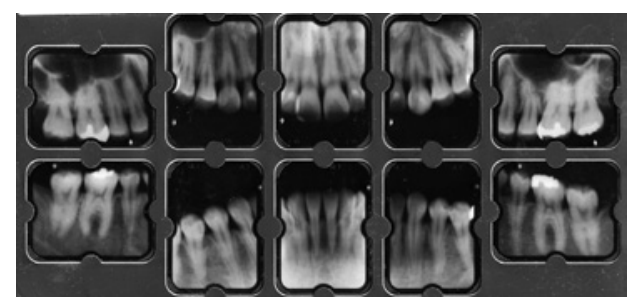

図 2 Panoramic radiography at first examination 初診時デンタルX線写真

表 1 Periodontal condition at first examination 初診時の歯周組織検査表
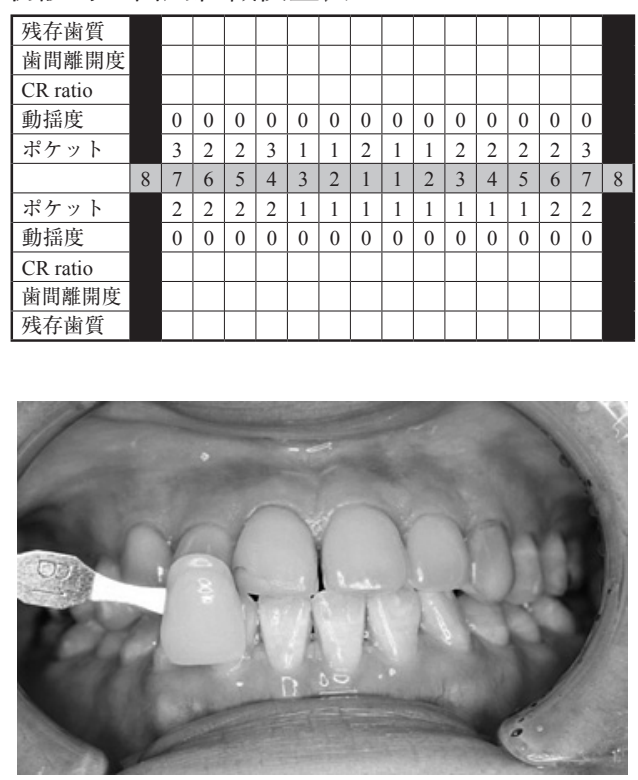

図 3 Shade taking before treatment 術前のシェードテイキング

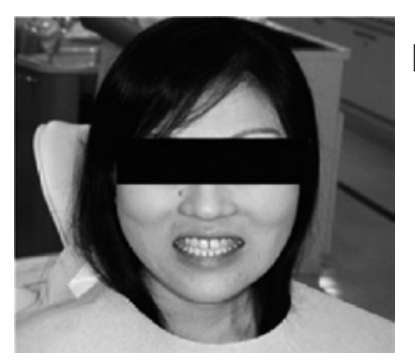

図 4 Facial view before treatment 術前の顔貌写真 


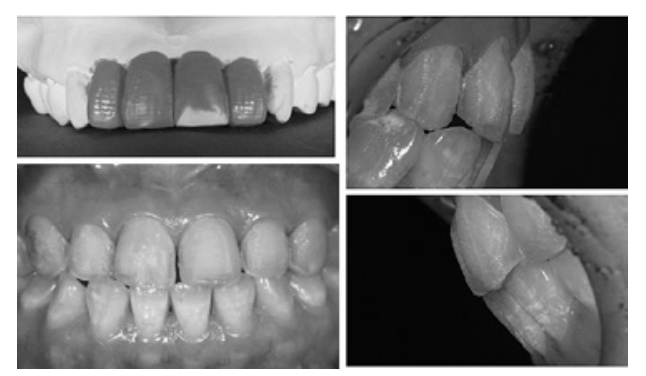

図 5 Preparation of PLV and diagnostic wax up PLV の形成と診断用ワックスアップ

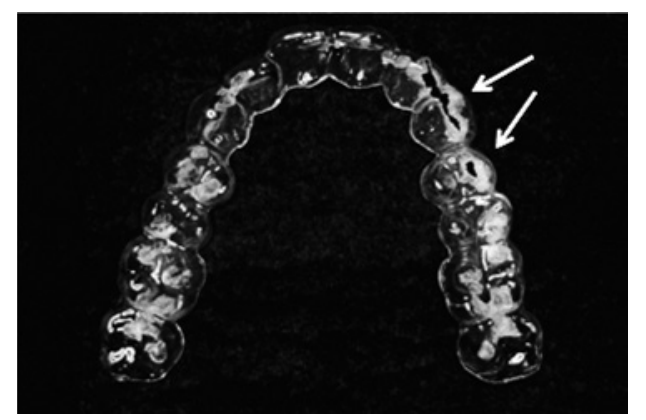

図 6 Perforation and friction notch on the trial nightguard

睡眠時に装着したナイトガードの穿孔と摩擦痕

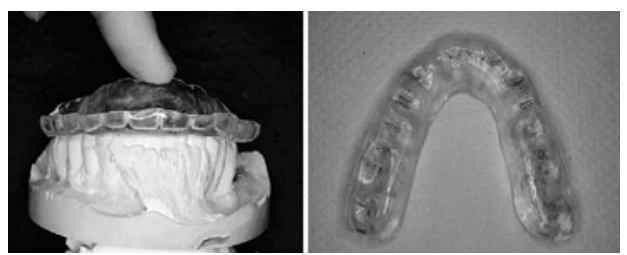

図 7 Maxillary flat sprint with group functional occlusion

グループファンクションを付与した上顎フラッ

トスプリント

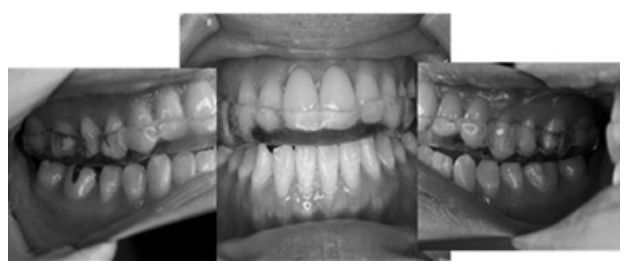

図 8 Intraoral view in wearing flat sprint

上顎フラットスプリント装着時の口腔内写真
一方，睡眠時ブラキシズムについては，チェアサイド で確認できる臨床徴候として問診と臨床検査を行い, 筆者の講座で使用している睡眠時ブラキシズムの診断 アルゴリズムを基に臨床診断を行った ${ }^{1)}$ 。まず問診にお いて自ら歯ぎしりをしている自覚はなかった。睡眠同 伴者はなく, 歯ぎしり音の指摘は得られなかったが, 起 床時の症状として閉口筋の疲労感を訴えた。また, 覚醒 時の噛みしめや咀嚼筋の疲労感はなく, 睡眠時ブラキ シズムのリスクファクターであるアルコールの常飲, 喫煙，抗精神薬の服用なども認められなかった。さら に，臨床検査では，上顎ラミネートベニアの破損およ び脱離に加え，左側への下顎滑走運動時に上顎左側小 臼歯部の咬耗面の一致と同部位の光沢が顕著に確認で きた。以上よりグラインディングタイプの睡眠時ブラ キシズム患者であり ${ }^{1-3)}$ ，睡眠時ブラキシズムによる正 中離開とラミネートベニアの破損および充填修復後の 着色による審美不良と診断した。治療方針は上顎前歯 ポーセレンラミネートベニアの再製作とし，睡眠時ブ ラキシズムに対して，上顎オクルーザルスプリントで 対応を行うこととした。

\section{III. 治療内容と経過}

\section{PLVの製作}

患者の要望を基準とした診断用ワックスアップを行
い，シリコンガイドを作製した。歯冠の厚みと形態を 確認した後，アンテリアコンタクトならびに犬歯誘導 を考慮して切縁を被覆する形態に，無麻酔下にて形成 を行った（図 5).PLV はプレス成型法にて製作し，色 調は A-2, 歯頸部には一部ステインを施した。試適後 トライインペーストで合着後の色調を確認した後, ラ ミネートベニアの被着面をリン酸エッチングおよびプ ライマー処理を行った。支台歯は洗浄, リン酸エッチ ング後, ベニアボンドをエナメル質および一部象牙 質に塗布, 乾燥後レジンセメント（リンクマスター, $\mathrm{GC}$, 東京, 日本) を塗布し光照射とエアーバリアで PLV の合着を完了した. 6 前歯はアルミ箔にてセパレー ションし，本重合後余剰セメントの除去を徹底した。 最後は研磨・咬合調整の順で装着を完了した。

\section{2. 睡眠時ブラキシズムへの対応}

睡眠時ブラキシズムが臨床的に強く疑われたため, PLV 装着後，上顎スプリントの製作を説明したが，ま ず患者の強い希望もあり，バキュームプレスによる厚 さ $1 \mathrm{~mm}$ のスプリントを製作した。その結果，約 2 週

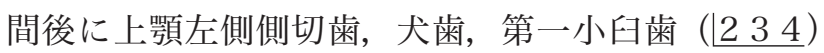
部に穿孔が，また全顎に渡る摩擦痕も認められ SB の レベルがプレスタイプのスプリントで対応不可能であ ることが明らかになった（図 6)。その後, 患者の同 意を得て通法により加熱重合夕イプのレジンを用いて 


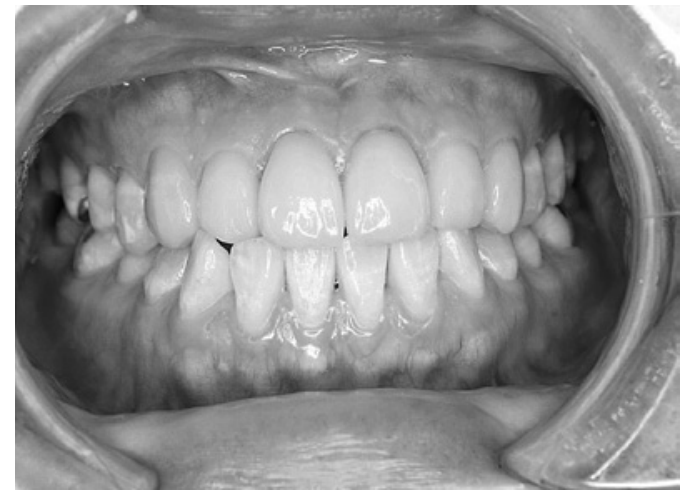

図 9 Intraoral photograph from anterior view after treatment 5 年経過後の口腔内写真正面観

上顎オクルーザルスプリントを製作し装着した。スプ リントの形態は習慣性閉口位において多点同時接触と し，側方咬合接触様式はグループファンクションとす るフラットスプリントとした。また，スプリントによ る咬合挙上量は前歯部において垂直被蓋＋ $1.0 \mathrm{~mm}$ に 設定した。（図 7,8）。

\section{3. 術後の経過}

PLV 装着後，6 カ月に一度のリコール時にはスプリ ントはほぼ毎日使用しているとのことであり，スプリ ント上に睡眠時ブラキシズムを示唆する咬耗が認めら れた。必要に応じてレジンの添加を行い, 継続的に使 用している。 2012 年には患者の希望もありスプリン トを再製作したが，これまで正中離開やチッピングは 起っておらず経過は良好である（図 9)。

\section{IV. 考 察}

睡眠時ブラキシズムは睡眠中に行われる歯ぎしりと 食いしばりの総称であり，その影響は顎口腔系に破棄 的な影響を与える可能性があるが，発症因子について は未だ特定されていない。

現時点では，睡眠時ブラキシズムを確実に抑制する 方法はなく，スプリントによって補綴装置への偽害作
用を最小限にするという方策が現実的である，本症例 では睡眠時ブラキシズムを有する患者に対してオク ルーザルスプリントを用いることにより，PLVを睡眠 時ブラキシズムの過大な力から保護し, 良好な予後を 確保できた。

スプリント療法のコンプライアンスについては，本 症例のように自らの睡眠時ブラキシズムに気づいてな い場合でも，その為害作用と適切な対応法を説明し， 実際にプレスタイプのスプリントで穿孔を経験し, そ の後製作した加熱レジン製のスプリント上の咬耗を持 続的に観察することにより患者の理解が深まり, 治療 に対する協力が得られた。

\section{V. 結 論}

本症例は睡眠時ブラキシズムの的確な診断と合理的 な対応を行うことにより, 予知性の高い補綴歯科治療 を可能とし，睡眠時ブラキシズムを有する患者へのラ ミネートベニア法による審美修復においても良好な予 後が期待できることを示した.

\section{文献}

1）加藤隆史, 馬場一美. 完全理解 睡眠時ブラキシズム科 学的根拠に基づき，補綴臨床で何をすべきか。ザ・クイ ンテッセンンス $2011 ; 30$ : 43-87.

2) Kato T, Lavigne G. Sleep bruxism: a sleep related movement disorder. Sleep Med Clin 2010; 5: 9-35.

3) Lavigne GJ, Cistulli PA, Smith MT (古谷野 潔編). Sleep medicine for dentists（歯科医師のための睡眠医 学 その実践的概要。東京：クインテッセンス出版; 2010, 109-116. ), 2009.

\footnotetext{
著者連絡先 : 岩佐 文則

干 145-8515 東京都大田区北千束 2-1-1

Tel: 03-3787-1151 内線 237

Fax: 03-3787-3971

E-mail: ft.iwasa@dent.showa-u.ac.jp
} 